\title{
Phytoprotection
}

\section{Entomopathogenic Nematodes - Save Biocontrol Agents for Sustainable Systems}

\section{Ralf-Udo Elhers}

Volume 79, numéro 4, 1998

OECD Workshop - Sustainable Pest Management, Safe Utilization of New Organisms in Biological Control. Montréal, Québec, Canada. September 27-30, 1998.

Atelier de l'OCDE - Gestion durable des ennemis des cultures, Utilisation sécuritaire de nouveaux organismes de lutte biologique. Montréal, Québec, Canada. 27-30 Septembre 1998.

URI : https://id.erudit.org/iderudit/706164ar

DOI : https://doi.org/10.7202/706164ar

Aller au sommaire du numéro

Éditeur(s)

Société de protection des plantes du Québec (SPPQ)l

ISSN

0031-9511 (imprimé)

1710-1603 (numérique)

Découvrir la revue

Citer cet article

Elhers, R.-U. (1998). Entomopathogenic Nematodes - Save Biocontrol Agents for Sustainable Systems. Phytoprotection, 79(4), 94-102.

https://doi.org/10.7202/706164ar d'utilisation que vous pouvez consulter en ligne. 


\title{
Entomopathogenic Nematodes
} - Save Biocontrol Agents for Sustainable Systems

\author{
Dr. Ralf-Udo Ehlers
}

Institute for Phytopathology, Christian-Albrechts-University Kiel, Dept. Biotechnology \& Biol. Control, Klausdorfer Str. 28-36, 24223 Raisdorf, Germany

\section{BIOLOGY}

Steinernema and Heterorhabditis (Rhabditida) are symbiotically associated with bacteria of the genera Xenorhabdus and Photorhabdus within the Enterobacteriaceae in the gamma subdivision of purple bacteria (Ehlers et al., 1988), respectively. Each nematode species has a specific association with one bacterium species (Akhurst \& Boemare, 1990; Ehlers \& Niemann, in press). Like other nematodes of the order Rhabditida, Steinernema and Heterorhabditis spp. form dauer (enduring) juveniles (DJs), which are morphologically and physiologically adapted for long term survival in the soil environment (Womersley, 1993; Glazer, 1996). DJs can be isolated from almost all habitats where soil insects occur. Whereas the few Heterorhabditis species are distributed all around the world, the majority of the Steinernema species seem to be restricted to certain geografical regions and other species, e.g. S. feltiae, are widly distributed (Hominick et al., 1996). The nematode dauer juveniles (DJ) carry between 0 to 250 cells of their symbiont in the anterior part of the intestine. The symbiotic bacteria are released into the haemolymph after penetration of the DJ into a suitable host insect. Inside the DJ the bacteria are well protected against detrimental conditions in the soil. Neither Xenorhabdus nor Photorhabdus spp. have ever been isolated from soil environments (Akhurst \& Boemare, 1990; Poinar, 1990). Accordingly, this phoretic relation seems to be of vital necessity for the associated bacteria. They totally depend on transmission by the DJ into a sterile environment like the insect's haemocoel, as they lack any means for survival in the soil environment (Morgan et al., 1997) or invasion of insect's haemocoel without the help of the DJ. Whereas Steinernema spp. can kill insects even without their symbiotic bacteria (Ehlers et al., 1997), Heterorhabditis spp. lack insect pathogenicity in the absence of $P$. luminescens. Bowen \& Ensign (1998) identified insecticidal proteins produced by $P$. luminescens with potential to substitute Bt toxins in transgenic plants.

Host-finding behaviour of DJs can differ within a population and can also be species specific. "Hunters" are highly mobile and a large proportion of their population tends to actively seek for suitable hosts. In populations of $S$. glaseri and Heterorhabditis spp. the majority of the individuals show this character. The sit-and wait "ambushers" often attach to soil particles and nictate, waiting for an insect to pass by and then attack. S. carpocapsae is a species with this behaviour (Gaugler, 1993). Penetration of the host insect occurs via natural openings or directly through the insect cuticle (Bedding \& Molyneux, 1982; Peters \& Ehlers, 1994). There are indications that the penetration process is supported by proteolytic factors produced by the exsheathed dauer juvenile (Roque et al., 1994). Upon reaching the haemocoel the DJ is recognized as non-self and insect defense mechanisms can eliminate the DJs through encapsulation (Peters \& Ehlers, 1997). Defence mechanisms against the bacteria also 
have been described (Götz et al., 1981). Providing the insect's defense mechanisms fail to eliminate the nematodebacterium complex, the insect dies 2-4 days after infection. Akhurst \& Dunphy (1993) and Simoes \& Rosa (1996) have summarized the current knowledge on the pathogenicity mechanisms of the nematode-bacterium complex and the interactions with the defense system of host insects. Once established inside the cadaver, the bacteria proliferate and produce suitable conditions for the nematode to grow and reproduce. The nematodes feed on cells of their symbiont and host tissue. Without the presence of the symbiotic bacteria in the insect cadaver the nematodes are unable to reproduce (Poinar \& Thomas, 1966). Infective DJs of Steinernema develop to amphimictic adults and Heterorhabditis spp. to self-fertilizing hermaphrodites. Their offspring either develop to DJs or to a F1 adult generation. Another adult generation (F2) is usually not developed. Instead, in response to depleting food resources, DJs are formed. Two to three weeks after colonisation of the host insect, the DJs leave the cadaver searching for new target insects in the soil.

\section{SAFETY AND REGISTRATION}

Entomopathogenic nematodes and their symbionts are environmentally safe and show no evidence of mammalian patho- genicity (Boemare et al., 1996, Ehlers \& Hokkanen, 1996). Besides what has been published in the scientifc literature, safety tests have been conducted by the Pasteur Institute (Boemare et al., 1996) and by commercial companies. Although these results have not been made public, the documentation was provided to the US agency APHIS. No attributes of the nematodes could be identified which would prohibit their use in biocontrol (R. Georgis, personal communication; Parkman et al., 1992).

The consensus view of the participants of a combined OECD and COST 819 workshop on introduction and commercial use of non-endemic nematodes for insect biological control (Ehlers \& Hokkanen, 1996) was that entomopathogenic nematodes (EPNs) possess specific biological and ecological features, which make their use in biological control exceptionally safe. All of the scientific evidence available supports the conclusion that EPNs are safe to the environment, as well as to the production and application personnel, to the general public, and to the consumers of agricultural products treated with EPNs. Only a few potential, but very remote risks could be identified (Tab. $1 \& 2$ ). Therefore it was recommended that EPNs should not be subject to any kind of registration.

The introduction of non-endemic nematode species, however, should be regulated. Species should be accurately identified, details of the origin, known distribution, probable host range and

Table 1. Possible risks to human health as identified by the expert group. Scale: $0=$ no risk at all, 1 = remote, 2 = slight, 3 = moderate, 4 = high, $5=$ very high risk.

\begin{tabular}{|c|c|c|}
\hline & Production \& Application Personnel & General Public \\
\hline 1. Toxicity & 1 & 0 \\
\hline 2. Allergenicity & 2 & 0 \\
\hline \multicolumn{3}{|l|}{ 3. Infectivity } \\
\hline nematodes & 0 & 0 \\
\hline bacteria & 1 & 0 \\
\hline 4. Carcinogenicity & 0 & 0 \\
\hline 5. Teratogenicity & 0 & 0 \\
\hline 6. Food and Feed & 0 & 0 \\
\hline \multicolumn{3}{|l|}{ 7. Pathogenicity of } \\
\hline hot-adapted strains & $?$ & $?$ \\
\hline
\end{tabular}


Table 2: Possible environmental risks of using EPNs, as identified by the experts. Risk rating as in Table 1. NTO = Non-Target Organsims

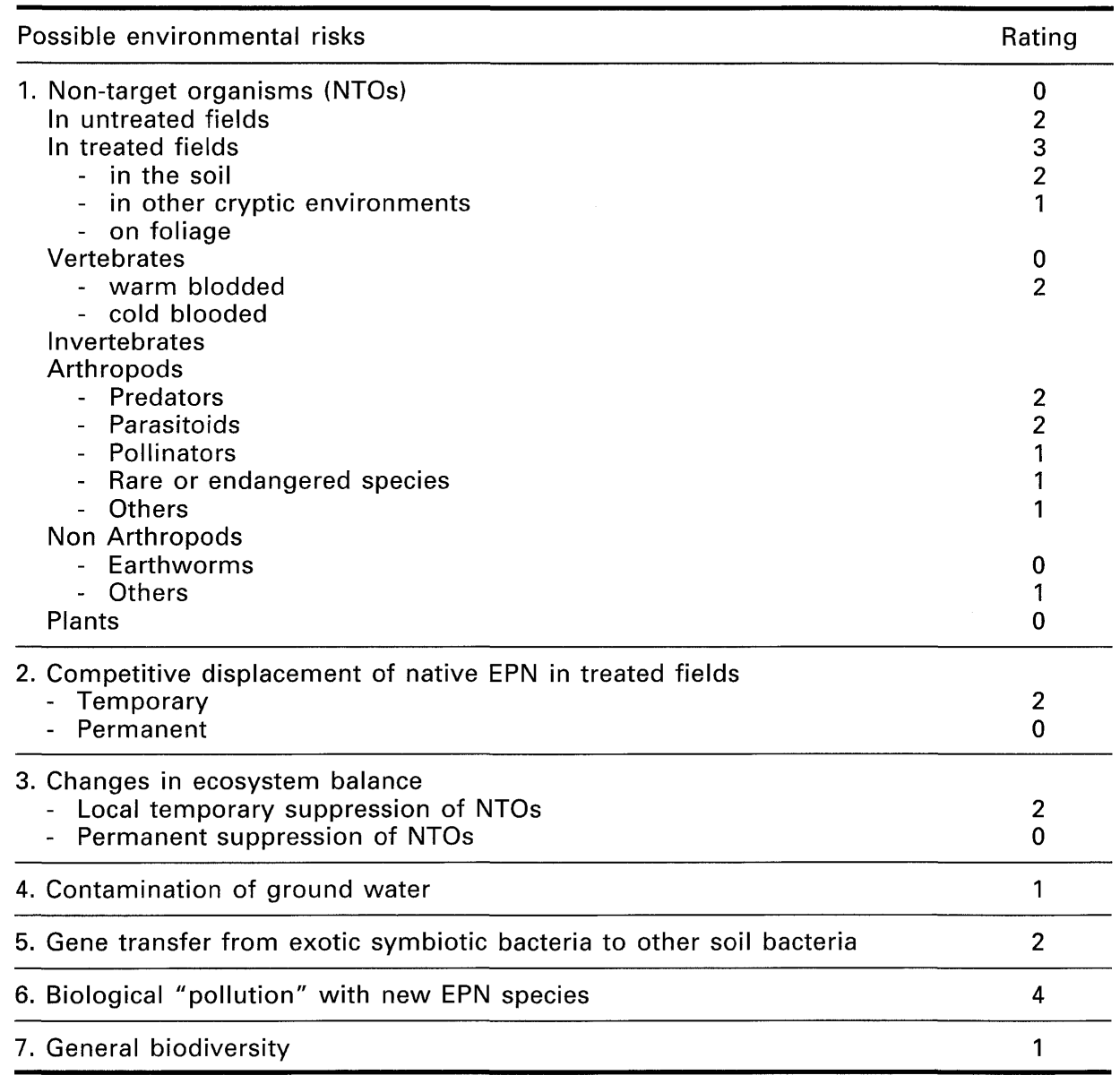

its safety to the user must be provided together with an expert opinion based on available information of the possible impact on non-target organisms. Nematodes are beneficial animals and although symbiotically associated with bacteria, in most countries they are not placed in the category of microorganisms for pest control. As such they are usually exempted from registration requirements, as documented for the United States by Gorsuch (1982). This makes the commercial development of nematode products even more attractive for industry as large costs related with registration can be avoided.

\section{COMMERCIAL USE OF EPNs}

Nematodes can be mass produced in in vitro culture. Their symbiotic bacteria can convert protein-rich media into suitable resources for the nematodes. A significant breakthrough in nematode biotechnology was the discovery of the symbiotic bacterium by Poinar \& Thomas (1965) and the development of in vitro production techniques on solid substrates applicable for nematodes of both genera (Bedding, 1981, 1984). Since then the commercial use of nematodes in high value crops in horticulture started. In industrilized countries 
the labour-intensive solid state production is often substituted by liquid culture in bioreactors. Liquid mass production started with $S$. carpocapsae, which was scaled up to 80.000 Itr. (Friedman, 1990). Yields of Heterorhabditis spp. liquid cultures are still highly variable (Ehlers et al., 1998). In the future, commercial development will rely solely on liquid culture technology as this is the only means for a development of nematode-based products for agricultural markets at economically reasonable prices.

The art of nematode formulation technology is to define and maintain environmental conditions which transfer the DJ into a quiescent state from which it can immediately recover when placed into the spraying tank. Formulation compounds, like clays or biopolymers, have the function to immobilize the nematodes, and all kinds of adjuvants and additives preserve favourable conditions for the nematode. Sufficient gas exchange and a stable moisture content have to be preserved. Shelf life of nematode based products of a few months is nowadays achieved at ambient temperatures not exceeding $30^{\circ} \mathrm{C}$. The DJ is resistant to shear forces and can bear pressure of $2,000 \mathrm{kPa}$ (Georgis, 1990), which is why DJs can be sprayed with conventional spraying equipment.

In the overall turnover in the biocontrol market, EPNs have reached the second position after Bacillus thuringiensis based products. Currently seven companies in Europe produce EPNs for commercial application. In 1994 world-wide nematode sales surpassed \$US 10 million. In Europe and the USA, larvae of the black vine weevil Otiorhynchus sulcatus are controlled in strawberries, craneberries, ornamentals and tree nurseries with Heterorhabditis spp., S. feltiae or S. carpocapsae (Georgis, 1992). Treatments in citrus plantations reduce root weevils (Curculionidae) by 50-65\% (Downing et al., 1991; Schroeder, 1990, 1992). Sciarid flies (Sciaridae) in mushroom cultures are reduced by $S$. feltiae strains by 51 94\% (Grewal \& Richardson, 1993; Grewal et al., 1993). Turf insect pests can be successfully controlled. The mole cricket Scapteriscus vicinus is controlled with S. scapterisci in Florida and Georgia (Redmond \& Georgis, 1993). White grubs (Scarabaeidae) in turf can be managed by application of Heterorhabditis spp. (e.g., Georgis \& Gaugler, 1991; Klein \& Georgis, 1992, Downing, 1994, Sulistyanto \& Ehlers, 1996). In China the peach borer (Carposina nipponensus) is an important pest of apples and pears (Jinxian, 1993), and several hundred hectares are already treated with S. carpocapsae (Doeleman, 1990). Also in China, this nematode is successfully introduced to control the cossid carpenterworm Holocerus insularis in shade trees (Huaiwen et al., 1993; Jinxian, 1993). S. carpocapsae is also used against flea larvae and pupae in soil in the USA.

\section{EPNs IN SUSTAINABLE SYSTEMS}

Little is known about the impact of naturally occuring EPN populations. The observations reported so far can be divided into relatively balanced hostnematode associations and epizootics. The association of $S$. kraussei with the false spruce webworm, Cephalcia abietis, in Central Europe is an example for a balanced system with a cumulative annual control of approximately $25 \%$ (Mracek, 1986; Eichhorn, 1988). In Austria Führer \& Fischer (1991) used lime to increase the soil pH in forest systems in order to enhance the host finding of the natural nematode popuation and they could increase the nematode infestation of $C$. abietis. Another example for an attempt to increase the naturally occurring EPN population by cultural methods is reported by Brust (1991). No-tillage and less intense weed control resulted in higher levels of nematode infestation, significantly higher corn yields and less root damage by the corn rootworm Diabrotica undecimpunctata howardi.

Epizootics have been observed in grub populations infested with Heterorhabditis sp. reaching $71 \%$ control in a sugarcane field (Akhurst et al., 1992) 
and $80 \%$ in the population of the garden chafer Phyllopertha horticola (Peters, 1996). In New Zealand an increasing infestation reaching $56 \%$ after a one-time release of $H$. bacteriophora was reported in the second year (Jackson \& Wouts, 1987). Since four years $H$. bacteriophora is used inundatively in Germany to control grubs ( $P$. horticola) in turf. On many plots treated with nematodes the grub population was below the damage threshold in following years (Ehlers \& Peters, 1998). These observation encourage further research to investigate the conditions necessary to obtain long-term effects through nematode inoculation.

The distribution of EPNs in the field seems to be related to the distribution of potential host insects. As the distribution of soil insect populations are usually patchy, the same is recorded for nematodes. Those species with a wide host range, e.g. S. feltiae, are found in almost every second soil sample, whereas Heterorhabditis spp. are seldomly encounted. The latter seem to have the potential to cause epizootics and thus have a potential for inoculative release. Their potential for long term survival seems to be poor. In contrast, $S$. feltiae is able to survive for long periodes without hosts available and thus is more abundant, but has not been observed to control more than $20 \%$ of a potential host population.

Nowadays, EPNs are used inundatively, however, the reports of natural occurance, their potential for long-term control and possible cultaral means of stabilizing their population should encourage research to investigate their potential as antagonists in sustainable systems.

\section{FUTURE PERSPECTIVES}

Currently, the market size in the different countries seldomly surpasses treatments of 500 hectares. The use in outdoor crops would involve much larger areas and consequently a an increase in liquid culture capacity. Considering the short shelf life of nematodes and the seasonal variation in the demand of agriculture markets, the production also becomes a logistic problem. The capacity and timing of mass production needs to be adapted to the market's seasonal demand (von Reibnitz \& Backhaus, 1994). To make available such quantities of entomopathogenic nematodes, the technology needs to be reproducible, liquid culture yields need to be further increased and DJ quality must be stabilized.

Significant progress also is needed in the improvement of the post harvest and application technology. Large nematode quantaties can only be handled when storage technology can guarantee a survival of the DJs at high quality. The objective of formulation improvement is to guarantee a shelf life of approximately 6 months at ambient temperature. This is already achieved with some, but not all nematode species. For field use, low volume application technology and the lack of irrigation facilities must also be considered. Currently, nematodes are applied with high volumes of water. Future efforts will have to consider adjuvants and additives in order to decrease the amount of water necessary for nematode application in the field. Research and development in application technology will also focus on an overall reduction of the nematode application density. Many of the nematodes applied never reach a target host (Curran, 1993). The improvement of the application technology and of the nematode's control potential by genetic means (Burnell \& Dowds, 1996) are possible measures to reduce the application density in the field. Together with progress in the liquid culture technology this will significantly contribute to lower application costs.

In conventional agriculture systems biocontrol products can not compete with chemical control measures. Therefore biologicals are only used in situation were chemicals fail, either due to resistance of the insect population or to survival in cryptic environments, or when the chemical control is restricted by legislation. Chemical compounds are to be degraded in the environment within two weeks after application, 
persistent pesticides have been banned. In contrast, the impact of biologicals can be long lasting. Sustainable agriculture and ecological farming practice will rely on the potential of biologicals. They can either develop cultural methods to increase and maintain the potential of antagonistic populations or, in the case where the antagonist is absent, they will rely on inundative release. Sustainability will largely depend on biological regulation of pest populations and EPNs contribute to the overall antagonistic potential in soil environments.

EPNs have many advantages over other control agents. They can be applied with conventional spraying equipment, chemical compounds cannot interfere with their control potential and they are usually exempted from registration (Ehlers \& Peters, 1995). Like microbial agents nematodes can easily be mass produced in liquid culture and stored maintaining their control potential for considerable time (Ehlers, 1996). They have a potential in inundative and inoculative release and have insignificant effects on non-target organisms (Bathon, 1996). They are mobile in the soil environment and can persist for years.

Other microbials need registration and the costs related with the registration cannot be justified taking into consideration the size of the potential markets. Transgenic plants met the same conditions as their development is equally expensive and they will be available only in the large scale markets. As long as registration policy is not changed, marketing of microbial control agents is prevented and nematodes will probably be the number one agents for insect control in soil environments.

- The question is whether long-term sustainable effects can be measured? Quantification of nematode populations is almost impossible and usually we cannot distinguish between released and endemic populations. Increases in yields of $5 \%$ or more are within the confidentiality range of our data.
- Another question is whether societies are willing to support the development of biocontrol agents and will subsidies costs related to safety tests?

- Biocontrol in sustainable systems will rely on a spectrum of possible agents. Are our politicians prepared to reduce the costly hurdles which are currently related with registration of microbial agents?

\section{REFERENCES}

AKHURST, R. J., BEDDING, R. A., BULL, R. M., \& SMITH, R. J. (1992) An epizootic of Heterorhabditis spp. (Heterorhabditidae: Nematoda) in sugar cane scarabaeida (Coleoptera). Fundamental \& applied Nematology, 15, 71-73.

AKHURST, R. J. \& BOEMARE, N. E. (1990) Biology and taxonomy of Xenorhabdus, in Entomopathogenic Nematodes in Biological Control (GAUGLER, R. \&. KAYA, H. K., Eds) CRC Press, Boca Raton, pp. 75-90.

AKHURST, R. J. \& DUNPHY, G. B. (1993) Tripartite interactions between symbiotically associated entomopathogenic bacteria, nematodes, and their insect hosts, in Parasites and Pathogens of Insects - Volume 2: Pathogens (BECKAGE, N. E., THOMPSON, S. N. \& FEDERICl, B. A., Eds). Academic Press, San Diego, pp. 1-23.

BEDDING, R. A. (1981) Low cost in-vitro mass production of Neoaplectana and Heterorhabditis species (Nematoda) for field control of insect pests. Nematologica 27, 109-114.

BEDDING, R. A. (1984) Large scale production, storage and transport of the insectparasitic nematodes Neoaplectana spp. and Heterorhabditis spp. Annals of Applied Biology 104, 117-120.

BATHON, H. (1996) Impact of entomopathogenic nematodes on non-target hosts. Biocontrol Science and Technology 6, 421-434.

BEDDING, R. A. \& MOLYNEUX, A. S. (1982) Penetration of insect cuticle by infective juveniles of Heterorhabditis spp. (Heterorhabditidae: Nematoda). Nematologica 28, 354-359.

BOEMARE, N. E., LAUMOND, C. \& MAULEON, H. (1996) Biology of nematode-bacterium complex. Biocontrol Science and Technology 6, 333-345. 
BOWEN, J. D. \& ENSIGN, J. C. (1998) Purification and characterization of a highmolecular-weight insecticidal protein complex produced by the entomopathgenic bacterium Photorhabdus luminescens. Applied \& Environmental Microbiology 64, 3029-3035.

BURNELL, A. M., \& DOWDS, B. C. A. (1996) The genetic improvement of entomopathogenic nematodes and their symbionts. Biocontrol Science and Technology 6, 435-447.

BURST, G. E. (1991) Augmentation of an endemic entomogenous nematode by agroecosystem manipulation for the control of a soil pest. Agriculture, Ecosystem \& Environment 36, 175-184.

CURRAN, J. (1993) Post-application biology of entomopathogenic nematodes in soil, in Nematodes and the Biological Control of Insect Pests (BEDDING, R. A., AKHURST, R. J. \& KAYA, H. K., Eds) CSIRO Publications, East Melbourne, pp. 67-77.

DOELEMAN, J. A. (1990) Economic Assessment Series 4. Benefits and Costs of Entomopathogenic Nematodes: Two Biological Control Applications in China. Australian Centre for International Agriculture Research, Canberra.

DOWNING, A. S. (1994) Effect of irrigation and spray volume on efficacy of entomopathogenic nematodes (Rhabditida, Heterorhabditidae) against white grubs (Coleoptera, Scarabaeidae). Journal of Economic Entomology 87, 643-646.

DOWNING, A. S., ERICKSEN, C. G. \& KRAUS, M. J. (1991) Field evaluation of entomopathogenic nematodes against citrus root weevils (Coleoptera: Curculionidae) in Florida citrus. Florida Entomologist 74, 584-586.

EHLERS, R.-U. (1996). Current and future use of nematodes in biocontrol: Practice and commercial aspects in regard to regulatory policies. Biocontrol Science \& Technology 6, 303-316.

EHLERS, R.-U. \& HOKKANEN, H. T. M. (1996) Insect biocontrol with non-endemic entomopathogenic nematodes (Steinernema and Heterorhabditis spp.): Conclusions and recommendations of a combined OECD and COST workshop on scientific and regulatory policy issues. Biocontrol Science and Technology 6, 295-302.

EHLERS, R.-U., LUNAU, S., KRASOMIL-OSTERFELD, K. \& OSTERFELD, K. H. (1998) Liquid culture of the entomopathogenic nematode-bacterium-complex Heterorhabditis megidis/Photorhabdus luminescens. BioControl 43, in press.
EHLERS, R.-U., \& NIEMANN, I. (1998) Molecular identification of Photorhabdus luminescens strains by amplification of specific fragments of the 16S ribosomal DNA. Systematic \& Applied Microbiology, in press.

EHLERS, R.-U. \& PETERS, A. (1995) Entomopathogenic nematodes in biological control: feasibility, perspectives and possible risks, in Biological Control-Benefits and Risks (HOKKANEN, H. M. T. \& LYNCH, J. M., Eds) Cambridge University Press, Cambridge, pp. 119-136.

EHLERS, R.-U. \& PETERS, A. (1998) Bekämpfung von Engerlingen auf Sportrasen. Rasen/Turf/Gazon 29, in press.

EHLERS, R.-U., WULFF, A. \& PETERS, A. (1997) Pathogenicity of axenic Steinernema feltiae, Xenorhabdus bovienii and the bacto-helminthic complex to larvae of Tipula oleracea (Diptera) and Galleria mellonella (Lepidoptera). Journal of Invertebrate Pathology 69, 212-217.

EHLERS, R.-U., WYSS, U. \& STACKEBRANDT, E. (1988) 16S rRNA cataloguing and the phylogenetic position of the genus Xenorhabdus. Systematic and Applied Microbiology 10, 121-125.

EICHHORN, O. (1988) Untersuchungen über die Fichtengespinstblattwespen Cephalcia spp. PANZ (Hymenoptera, Pamphiliidae) II. Die Larven- und Nymphenparasiten. Journal of Applied Entomology 105, 105-140.

FRIEDMAN, M. J. (1990) Commercial production and development, in Entomopathogenic Nematodes in Biological Control (GAUGLER, R. \& KAYA, H. K., Eds) CRC Press, Boca Raton, pp. 153-172.

FÜHRER, E. \& FISCHER, P. (1991) Towards integrated control of Cephalcia abietis, a defoliator of Norway spruce in central Europe. Forest Ecology and Management 39, 87-95.

GAUGLER, R. (1993) Ecological genetics of entomopathogenic nematodes, in Nematodes and the Biological Control of Insect Pests (BEDDING, R., AKHURST, R. J. \& KAYA, H. K., Eds) CSIRO, East Melbourne, pp. 89-95.

GEORGIS, R. (1990) Formulation and application technology, in Entomopathogenic Nematodes in Biological Control (GAUGLER, R. \& KAYA, H. K., Eds) CRC Press, Boca Raton, pp. 173-191.

GEORGIS, R. (1992) Present and future prospects for entomopathogenic nematode products. Biocontrol Science and Technology 2, 83-99. 
GEORGIS, R. \& GAUGLER, R. (1991) Predictability in biological control using entomopathogenic nematodes. Journal of Economic Entomology 84, 713-720.

GLAZER, I. (1996) Survival mechanisms of entomopathogenic nematodes. Biocontrol Science and Technology 6, 373-378.

GORSUCH, A. M. (1982) Regulations for the enforcement of the FIFRA exemption from regulation of certain biocontrol agents. US Federal Register 47-23928-23930.

GÖTZ, P., BOMAN, A. \& BOMAN, H. G. (1981) Interaction between insect immunity and an insect-pathogenic nematode with symbiotic bacteria. Proceedings of the Royal Society London B212, 333-350.

GREWAL, P. S., GAUGLER, R. \& SELVAN, S. (1993) Host recognition by entomopathogenic nematodes: behavioral response to contact with host feces. Journal of Chemical Ecology 19, 1219-1231.

GREWAL, P. S. \& RICHARDSON, P. N. (1993) Effects of application rates of Steinernema feltiae (Nematoda: Steinernematidae) on biological control of the mushroom fly Lycoriella auripila (Diptera: Sciaridae). Biocontrol Science and Technology 3, 29-40.

HOMINICK, W. M., REID, A. P., BOHAN, D. A. \& BRISCOE, B. R. (1996) Entomopathogenic nematodes: biodiversity, geographical distribution and the Convention on Biological Diversity. Biocontrol Science and Technology 6, 317-331.

HUAIWEN, Y., GANGYING, Z., SHANAGO, Z. \& HENG, J. (1993) Biological control of tree borers (Lepidoptera: Cossidae) in China with the nematode Steinernema carpocapsae, in Nematodes and the Biological Control of Insect Pests (BEDDING, R., AKHURST, R. J. \& KAYA, H. K., Eds) CSIRO, East Melbourne, pp. 33-40.

JACKSON, T. A. \& WOUTS, W. M. (1987) Delayed action of an entomophagous nematode Heterorhabditis sp. (V16) for grass grub control. Proceeding of the 40th New Zealand Weed and Pest Control Conference, 33-35.

JINXIAN, W. (1993) Control of the fruit moth, Carposina niponensis, using entomopathogenic nematodes, in Nematodes and the Biological Control of Insect Pests (BEDDING, R., AKHURST, R. J. \& KAYA, H. K., Eds) CSIRO, East Melbourne, pp. 59-65.

KLEIN, M. G. \& GEORGIS, R. (1992) Persistence of control of Japanese beetle (Coleoptera: Scarabaeidae) larvae with steinernematid and heterorhabditid nematodes. Journal of Economic Entomology 85, 727-730.
MORGAN, J. A. W., KUNTZELMAN, V., TAVENOR, S., OUSLEY, M. A. \& WINSTANLEY, C. (1997) Survival of Xenorhabdus nematophilus and Photorhabdus luminescens in water and soil Journal of Applied Microbiology 83, 665-670.

MRACEK, Z. (1986) Nematodes and other factors controlling the sawfly Cephalcia abietes (Pamphilidae: Hymenoptera), in Czechoslovakia. Forest Ecology \& Management, 15, 75-79.

PARKMAN, J. P., THURSTON, G. S. \& GAUGLER, R. (1992) Proceedings of the beneficial nematode panel, in Proceedings of a USDA/CSRS National Workshop: Regulations and Guidelines: Critical Issues in Biological Control (CHARUDATTAN, R. \& BROWNING, H. W., Eds) Institute of Food and Agricultural Sciences, University of Florida, Gainesville, pp. 173176.

PETERS, A. (1996) The natural host range of Steinernema and Heterorhabditis spp. and their impact on insect populations. Biocontrol Science \& Technology 6, 389402.

PETERS, A. \& EHLERS, R.-U. (1994) Susceptibility of leatherjackets (Tipula paludosa and T. oleracea; Tipulidae: Nematocera) to the entomopathogenic nematode Steinernema feltiae. Journal of Invertebrate Pathology 63, 163-171.

PETERS, A. \& EHLERS, R.-U. (1997) Encapsulation of the entomopathogenic nematodes Steinernema feltiae in Tipula oleracea. Journal of Invertebrate Pathology 69, 218-222.

POINAR, G. O., JR. (1990) Biology and taxonomy of Steinernematidae and Heterorhabditidae in Entomopathogenic Nematodes in Biological Control (GAUGLER, R. \& KAYA, H. K., Eds) CRC Press, Boca Raton, pp. 23-61.

POINAR, G. O., JR., \& THOMAS, G. M. (1965) A new bacterium, Achromobacter nematophilus sp. nov. (Achromobacteriaceae: Eubacteriales), associated with a nematode. International Bulletin of Bacteriological Nomenclature and Taxono$m y, 15,249-252$.

POINAR, G. O., JR. \& THOMAS, G. M. (1966) Significance of Achromobacter nematophilus Poinar and Thomas (Achromobacteriaceae: Eubacteriales) in the development of the nematode, DD-136 (Neoaplectana sp., Steinernematidae). Parasitology 56, 385-390.

REDMOND, C. T. \& GEORGIS, R. (1993) Entomopathogenic nematodes as biopesticides for control of turfgrass insects, in International Turfgrass Society Research Journal 7, 398-404. 
ROQUE, P., RIBEIRO, C., CRUZ, N. \& SIMOES, N. (1994) Chemical factors released by Steinernema carpocapsae correlated with the penetration in the insect host, in Sixth International Colloquium on Invertebrate Pathology and Microbial Control - Second International Conference on Bacillus thuringiensis Society for Invertebrate Pathology, Montpellier, p. 277.

SCHROEDER, W. J. (1990). Entomopathogenic nematodes for root weevil control in citrus, in Proceedings of the Fifth International Colloquium of Invertebrate Pathology and Microbial Control, Society for Invertebrate Pathology, Adelaide, p. 267.

SCHROEDER, W. J. (1992) Entomopathogenic nematodes for control of root weevils of citrus. Florida Entomologist 75, 563-567.

SIMOES, N. \& ROSAS, J. S. (1996) Pathogenicity and host specificity of entomopathogenic nematodes. Biocontrol Science \& Technology 6, 403-411.
SULISTYANTO, D. \& EHLERS, R.-U. (1996) Efficacy of the entomopathogenic nematodes Heterorhabditis megidis and Heterorhabditis bacteriophora to control grubs (Phyllopertha horticola and Aphodius contaminatus) in golf course turf. Biocontrol Science and Technology 6, 247-250.

VON REIBNITZ, C. \& BACKHAUS, G. F. (1994) Untersuchungen zum Bedarf biologischer Pflanzenschutzverfahren gegen Otiorhynchus spp. im Gartenbau und zur Kostenstruktur der Produktionsverfahren für entomopathogen Nematoden (Heterorhabditis). Gartenbauwissenschaft 59, 199-206.

WOMERSLEY, C. Z. (1990) Dehydration survival and anhydrobiotic potential, in Entomopathogenic Nematodes in Biological Control (GAUGLER, R. \& KAYA, H. K., Eds) CRC Press, Boca Raton, pp. 117-138. 